\title{
Understory vegetation indicators of anthropogenic disturbance in longleaf pine forests at Fort Benning, Georgia, USA
}

\author{
Virginia H. Dale $^{\mathrm{a}, *}$, Suzanne C. Beyeler ${ }^{\mathrm{b}, 1}$, Barbara Jackson ${ }^{\mathrm{c}}$ \\ a Environmental Sciences Division, Oak Ridge National Laboratory, Oak Ridge, TN 37831-6036, USA \\ ${ }^{\mathrm{b}}$ Institute of Environmental Sciences, Miami University, Oxford, OH 45058, USA \\ ${ }^{c}$ Computer Science and Mathematics Division, Oak Ridge National Laboratory, Oak Ridge, TN 37831-6038 USA
}

Received 22 October 2001; accepted 18 December 2001

\begin{abstract}
Environmental indicators for longleaf pine (Pinus palustris) ecosystems need to include some measure of understory vegetation because of its responsiveness to disturbance and management practices. To examine the characteristics of understory species that distinguish between disturbances induced by military traffic, we randomly established transects in four training intensity categories (reference, light, moderate, and heavy) and in an area that had been remediated following intense disturbance at Fort Benning, GA. A total of 134 plant species occurred in these transects with the highest diversity (95 species) in light training areas and the lowest (16 species) in heavily disturbed plots. Forty-seven species were observed in only one of the five disturbance categories. The variability in understory vegetation cover among disturbance types was trimodal ranging from less than 5\% cover for heavily disturbed areas to $67 \%$ cover for reference, light, and remediated areas. High variability in species diversity and lack of difference in understory cover led us to consider life-form and plant families as indicators of military disturbance. Life-form successfully distinguished between plots based on military disturbances. Species that are Phanerophytes (trees and shrubs) were the most frequent life-form encountered in sites that experienced light infantry training. Therophytes (annuals) were the least common life-form in reference and light training areas. Chamaephytes (plants with their buds slightly above ground) were the least frequent life-form in moderate and remediation sites. Heavy training sites supported no Chamaephytes or Hemicryptophytes (plants with dormant buds at ground level). The heavy, moderate, remediated, and reference sites were all dominated by Cryptophytes (plants with underground buds) possibly because of their ability to withstand both military disturbance and ground fires (the natural disturbance of longleaf pine forests). Analysis of soils collected from each transect revealed that depth of the A layer of soil was significantly higher in reference and light training areas which may explain the life-form distributions. In addition, the diversity of plant families and, in particular, the presence of grasses and composites were indicative of training and remediation history. These results are supported by prior analysis of life-form distribution subsequent to other disturbances and demonstrate the ability of life-form and plant families to distinguish between military disturbances in longleaf pine forests. ( 2002 Elsevier Science Ltd. All rights reserved.
\end{abstract}

Keywords: Longleaf pine; Indicators; Life-form; Disturbance; Family diversity

\footnotetext{
* Corresponding author. Tel.: +1-865-576-8043; fax: +1-865-576-8543.

E-mail address: vhd@ornl.gov (V.H. Dale).

${ }^{1}$ Current address: The Department of Natural Resources, University of Illinois, Champaign, Illinois 61820, IL.
}

\section{Introduction}

Resource managers need a basic understanding of potential effects of human activity on ecological conditions. Human activity may influence a variety 
of ecological attributes including the presence of species, populations, and communities as well as the occurrence, rate, or scale of processes (Angermeier and Karr, 1994). Understanding the implications of anthropogenic disturbances on an ecological system is complicated by variability in ecological response. Identification of indicators which capture key ecological responses to human actions provides a useful tool for improving understanding of ecological effects and for monitoring and management.

Longleaf pine (Pinus palustris) forests are a system in which understanding effects of anthropogenic activity is necessary for resource management. Forests of the southeastern United States comprise a landscape that has experienced significant anthropogenic activity in the form of land development, resource utilization, and changes to the natural disturbance regimes. Anthropogenic activity within a landscape is typically expressed as a complex gradient of altered ecological components and changes in natural disturbance dynamics and succession patterns (Guntenspergen and Levenson, 1997). Prior to European settlement, longleaf pine forests covered 25-35 million hectares (ha) of the southeastern Coastal Plain landscape (Frost, 1993). By the 1900s, less than 10\% of the original stands remained (Frost, 1993). Today only two million hectares of the pre-settlement forest endures (Quicke et al., 1994). The loss and degradation of the longleaf pine forest is mainly attributed to land-use change, timber harvest, and fire suppression (Haywood et al., 1998; Gilliam and Platt, 1999). Since the longleaf pine forests are a fire-adapted system, it is the absence of regular light ground fires that is a disturbance to these forests. Fires reduce the growth of hardwoods into the overstory.

The need for a clear understanding of human impacts on longleaf pine forests takes on even greater importance when considering the fact that much of the remaining longleaf pine forest supports not only critical ecological processes but also a multitude of ecosystem services (Noss, 1989). For example, the federally endangered red-cockaded woodpecker (Picoides borealis) is a nonmigratory bird endemic to the longleaf pine forests in the southeastern United States. A prime cause of decline in red-cockaded woodpecker populations is the loss and degradation of longleaf pine forests. Reduction of the woodpecker population would also induce decline of the 23 species that inhabit holes in living trees uniquely created by these birds (Dennis, 1971).

One way to maintain the diverse ecological services of the longleaf pine forests entails reducing the amount of hardwood in-growth that, at first, compromises the understory and, eventually, alters overstory composition. As the hardwood trees grow into the canopy, the red-cockaded woodpeckers and other species unique to these forests tend to abandon the stands (Noss, 1989). Thus, the status of the understory composition and structure is a critical indicator of future condition of the longleaf pine forest (James et al., 2001). Unfortunately, the attributes and dynamics of this forest layer are not well-known, particularly for those systems that do not support the wire grass (Aristida stricta Michx.) community typical of the understory of some longleaf pine forests (Noss, 1989). Although an understanding of the cause and effect relationships of human modifications and alterations of longleaf pine systems is developing (Platt et al., 1988a,b; Frost, 1993; McCay, 2000), much still remains to be learned about human impacts on the understory in order to predict how human activities affect the ecological system.

Approximately, $75 \%$ of the longleaf forest is in private ownership serving a diversity of purposes including recreation and resource extraction. The remaining land is public. Almost without exception, the larger patches of longleaf pine forest are under federal ownership, a significant portion of which is on Department of Defense (DoD) lands (Walker, 1999). These large patches of intact forest best represent the ecological condition of the longleaf pine forest and tend to support the highest number of native species (Noss, 1989).

The longleaf pine stands on military installations are not only important forest reserves; they also provide suitable terrain for military training. In order to continue to meet the joint but seemingly incongruous needs of habitat reserves and military training, a means to monitor impacts of training should be developed and implemented. A critical challenge is to construct management procedures based on cost-effective monitoring plans that allow multiple land-use activities to take place while at the same time maintaining the ecological services of natural resources for the majority of the installation. There is a need on most military lands for the designation of sacrifice areas where training activities involving tracked vehicles and range practices must take place at the expense of ecological 
integrity. However, some attempts are made to minimize impacts through soil conservation measures. In contrast, dismounted training that also occurs on the installation appears to have minimal immediate impact on the forest stands. Differences subsequent to military foot traffic occur in soil infiltration rates, erosion, above ground biomass, and litter (Whitecotton et al., 2000). Yet, effects of foot traffic on the understory vegetation and over the long-term are not well-known.

Our perspective is that a suite of indicators ranging from microbiologic to landscape metrics is necessary to capture the full spatial, temporal, and ecological complexity of impacts that should be measured. Potential indicators should be considered in a spatially hierarchical fashion and for all gradients deemed important at a site. Placing potential indicators on a spatial axis (e.g. Fig. 1) provides a means to ensure that information is considered across spatial scales. Alternatively, it is important to include indicators that encompass the diversity of responses over time (so that one is not just measuring short-term responses of the system). In a similar fashion, as depicted in this figure, all major gradients should be included in the analysis of potential indicators. Thus, it is useful to consider the representativeness of indices across major physical gradients (e.g. soils, geology, land-use) and across gradients in disturbance regimes.

This study is part of a larger project designed to investigate indicators that would be useful to augment current sampling regimes at military bases and typical of other actively managed sites. Current ecological monitoring on military lands, the land condition trend analysis (LCTA) (Diersing et al., 1992), does not incorporate the diversity of indicators that are necessary for monitoring changes and responses to land as shown in Fig. 1. We hypothesized that understory conditions are a key element in the suite of indicators that can reflect differences in military training intensity. While some of the indicators from the proposed suite are designed to measure changes that occur over the long-term, understory vegetation is the element representing ecological changes that may occur over a few years to decades. Before such a suite can be adopted, it is necessary to evaluate how effectively the component indicators represent changes and susceptibility of ecological systems to military training. The purpose of this paper is to examine the ability of understory vegetation to indicate differences in disturbance regimes.

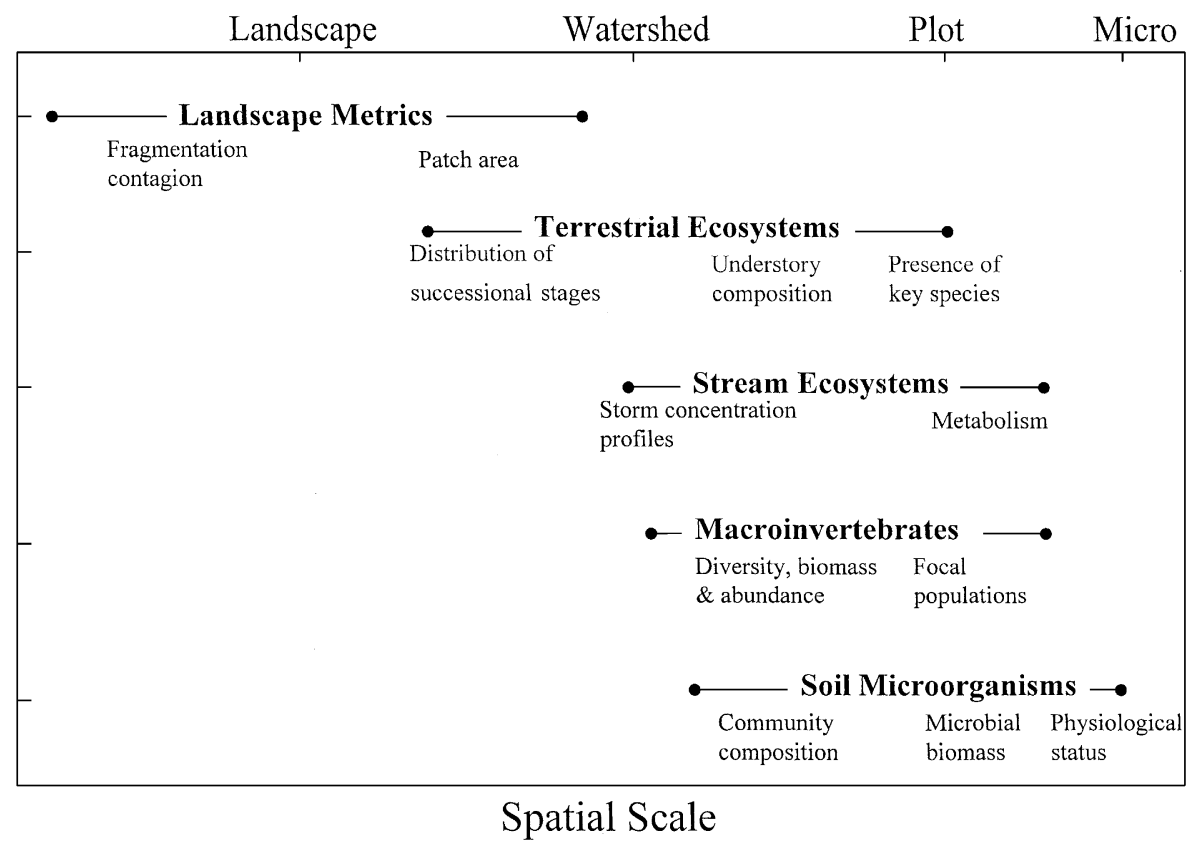

Fig. 1. Spatial hierarchical overlap of a suite of ecological indicators for Fort Benning, GA. 


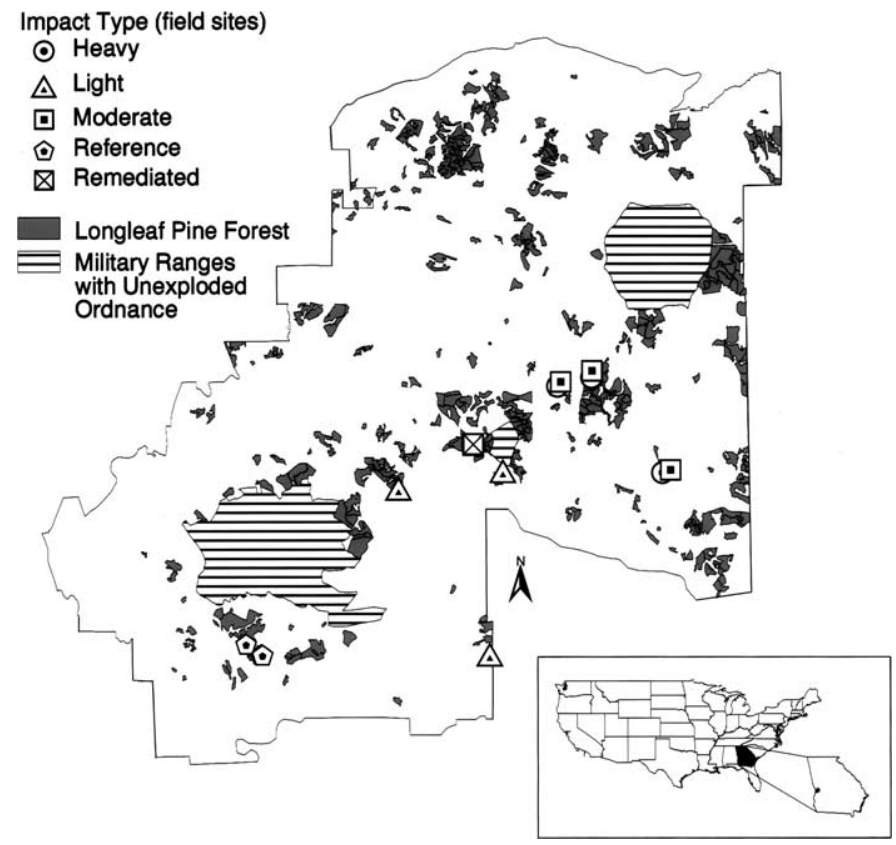

Fig. 2. Map of Fort Benning showing the location of field sites in relation to longleaf pine forest and military ranges that contain unexploded ordnance. Not that several sites are so close that the symbols overlap. The inset depicts the location of Fort Benning in western Georgia and Georgia in the southeastern United States.

\section{Study site}

The study was conducted at the Fort Benning Army Installation which occupies 73,503 ha in Chattahoochee, Muscogee, and Marion Counties of Georgia and Russell County of Alabama (Fig. 2). The climate at Fort Benning is humid and mild with rainfall occurring regularly throughout the year. The warmest months are July and August with average daily maximum and minimum temperatures of 37 and $15^{\circ} \mathrm{C}$, respectively. The coldest months are January and February with an average daily maximum and minimum temperature of 15.5 and $-1{ }^{\circ} \mathrm{C}$, respectively. Annual precipitation averages $105 \mathrm{~cm}$ with October being the driest month.

Fort Benning is located within the southern Appalachian Piedmont and Coastal Plains and is considered part of the southeastern Mixed Forest Province of the subtropical division (Bailey, 1995). The northern boundary of the installation lies along a transition zone between the Piedmont and Upper Coastal Plain. The installation is comprised of five major geologic formations: undifferentiated alluvium and mixed terrace deposits; Cusseta formation, which is mostly micaceous sand; Bluffton formation, a layered micaceous sand; Tuscaloosa formation; and the Eutaw formation (Roemer et al., 1994). The soils are constituted of a combination of clay beds and weathered Coastal Plain material as well as alluvial deposits from the Piedmont. Eight soil associations form the majority of the soil on the installation. Lakeland-Troup, Orangeburg-Dothan-Ailey, and Raanoke-leaf soil associations occupy the higher elevations. BibbChewacla-Rains, Ochloknee-Toccoa, Augusta-Ocholocknee, and Susquehanna-Duplin-Esto are located on the alluvial flood plains and terraces. Undifferentiated rough gullied land occurs in the southeast portion of the installation (Elliot et al., 1995).

Historically, the land was cleared and actively farmed first by native American and later by European settlers (Kane and Keeton, 1998). Fort Benning was established in 1918, and all farming stopped as landowners were relocated (which occurred up to 1945). Military training ensued for the following 
eight decades with heavy training land impacts occurring only in selected portions of the installation. Some timber harvesting and thinning continued, and the longleaf pine forests were subjected to regular low level fires for management purposes (Jack Greeley, personnel communication 1999, Fort Benning, GA).

Fort Benning contains several unique environmental features probably because the Fort Benning army installation was protected from farming and urban development which occupies much of the surrounding region. The presence of the federally-listed red-cockaded woodpecker is one reason why this study focused on the longleaf pine ecosystem. However, there are other rare species and habitats at Fort Benning, including the gopher tortoise (Gopherus polyphemus) and relict trillium (Trillium reliquum). Minimizing conflicts between the rare species and military land-use is a key goal of land management activities at the installation.

The presence of natural vegetation enables realistic training scenarios involving cover, concealment, or line-of-sight firing constraints. In order that Fort Benning can meet its mission needs now and into the future, the natural resources that provide the training context must be managed such that they are ecologically sustainable. With appropriate measurements and management, the retention of the training mission will also protect rare habitats and species at Fort Benning and other military installations.

The installation is a center for both dismounted and mechanized training, and, therefore, land-use focuses on military training (Waring et al., 1990). Maneuver areas are subject to a range of training activities such as dismounted infantry, mechanized forces, munitions detonation, biovac sites, landing strips and pads, and drop zones for airborne training (USAIC, 2001). Impacts of maneuver training activities on natural resources vary from direct removal or damage of vegetation, digging activities, ground disturbance from vehicles, soil compaction, soil erosion, and sedimentation. The degree and extent of the impacts of training activities depend on the type of training activity, time of year, intensity (e.g. the number of solders or vehicles per area per unit time), and how frequently the area is exposed to training activity. Further, different types of training typically occur irregularly over the landscape, and in many cases overlap, creating localized gradients of impacts. This study was limited to maneuver training areas and, thus, does not include firing ranges, ordinance impact areas, or cantonment areas. Our goal was to develop valid and repeatable measures of impacts of training on understory of longleaf pine forests.

\section{Experimental design}

Study site locations were on land suitable for longleaf pine growth. Determination of potential site locations was achieved through a combination of existing forest stand information (Bob Larimore, personal communication, 1999, Fort Benning, GA) and county soil surveys of the United States Department of Agriculture Natural Resource Conservation Service (USDA NRCS, 1924, 1983, 1993, 1997). We overlaid an image of the United States Forest Service forest stand classification onto USDA NRCS soil maps for the area of land within the Fort Benning boundary. A final map was then created depicting locations of soils associated with longleaf pine within the installation boundary, and study sites were selected from those areas. Longleaf pine stands currently comprise approximately 5800 ha of the total area of Fort Benning (USAIC, 2001). Soils favorable to the establishment and growth of longleaf pine make up approximately 65,900 ha (about $90 \%$ of the total area).

The study was designed using a stratified sampling methodology. The sampling sites were blocked into five training intensity categories: reference, light, moderate, heavy, and remediation. Reference areas experience little to no training activities and are often in exclusion zones around firing ranges. Light impact areas are limited to dismounted training and individual orienteering activities. Moderate impact areas occur adjacent to tank training zones and are, thus, exposed to some tracked vehicle maneuvers, as well as limited vehicle and infantry traffic. Heavy impact areas are used exclusively for wheeled and tracked vehicle training exercises. The classification of each site was primarily based on historical records of training activity; however, due to the variability of training intensity over space, final site selection was achieved through field reconnaissance and discussions with the Fort Benning natural resource personnel.

The remediation area is located in the uplands of the McKenna Drop Zone that was cleared in 1988 and subsequently rehabilitated (but was not used for 
training). It is currently off-limits to military training and testing. Revegetation efforts involved liming, fertilizing, and seeding with mixtures of grasses and legumes selected to increase vegetative cover and reduce run-off rates [e.g. giant reed (Arundo donax), bermuda grass (Cynodon dactylon), little bluestem (Adropogon scoparius), maidencain (Panicum hemitomom), pensacola bahiagrass (Paspalum notatum), alamo switchgrass (Panicum virgatum), weeping lovegrass (Eragrostis curvula), lespedeza sericea (Lespedeza cuneta, var. Sericia) and lespedeza interstate (Lespedeza cuneta, var. Interstate)].

Three transects were located in each of the reference, light, moderate, and heavy training classifications, and two transects were located in the remediation areas. Each of the 14 transects was established at a random distance and direction from a selected location.

Five circular plots were established along each transect at intervals of $15 \mathrm{~m}$ between the centers. The circular plot size of $5 \mathrm{~m}$ radius was determined based upon a species-area curve constructed for the reference site using the technique described by Barbour et al. (1980). At that size plot, 31 understory species occurred. Within each plot, all species of understory vegetation (less than one meter in height) were identified and assigned a cover class using a modified Braun-Blanquet (1932) cover system (based on Clarke, 1986) (Table 1).

Bråkenhielm and Qinghong (1995) have demonstrated that visual estimates provide the most accurate, sensitive, and precise measure of vegetation cover compared to point frequency and subplot frequency

Table 1

Key of the modified Braun-Blanquet (1932) cover classification system $^{\mathrm{a}}$

\begin{tabular}{ll}
\hline $\begin{array}{l}\text { Cover-abundance } \\
\text { class }\end{array}$ & $\begin{array}{l}\text { Species cover and } \\
\text { distribution characteristic }\end{array}$ \\
\hline 0 & No plants present \\
1 & Less than 1\% cover; $1-5$ small individuals \\
2 & Less than 1\% cover; many small individuals \\
3 & Less than 1\% cover; few large individuals \\
4 & $1-5 \%$ cover \\
5 & $5-12 \%$ cover \\
6 & $12-25 \%$ cover \\
7 & $25-50 \%$ cover \\
8 & $50-75 \%$ cover \\
9 & $75-100 \%$ cover \\
\hline
\end{tabular}

${ }^{\text {a }}$ Modified from Table 2.3; Clarke (1986). methods. Thus, visual estimates of understory cover were used in this study. We came to a clear agreement in the field as to the appearance of each cover class. Individual species cover scores could not exceed 100\%; however, cumulative cover scores for all species associated with an individual plot could be larger than $100 \%$. All species were also classified using Raunkiaer's life-form classification system (Kershaw and Looney, 1985) based on the height of perennating buds.

Understory vegetation included all shrubby and herbaceous vegetation as well as trees under $5 \mathrm{~cm}$ diameter at breast height (DBH). In addition, canopy cover, canopy species, size of trees greater than $5 \mathrm{~cm}$ $\mathrm{DBH}$, evidence of human disturbance, and depth of soil A horizon were recorded for each plot. The soil depth was meant to provide a quantitative measure of disturbance. In order to establish maximum stand age, we obtained two tree cores from each of the four largest trees in the immediate vicinity of each transect.

All species identification and characteristic descriptions were based on Godfrey (1988) and Radford et al. (1968). In a few cases plants could only be identified at the genus level. Understory oak had great plasticity, and distinguishing between saplings of the eight oak species was difficult. In addition, three distinct species of Prunus were observed, but due to a lack of a terminal inflorescence, two of the species were unidentifiable. Finally, one species of Desmodium was identified as clearly distinct from all other Desmodium species found within the study plots but was bearing no fruit, therefore rendering it impossible to identify.

Statistical analysis was performed to test for differences between the training intensities. Analysis of variance (ANOVA) was used to examine for differences in the mean cover scores for all species found within the plots (i.e. zeroes were eliminated). Oneway ANOVA and Cochran-Mantel-Haenszel statistical test (Cochran, 1954; Mantel and Haenszel, 1959; Mantel, 1963) were conducted to see if there were differences in the frequency of cover ranks by life-form within a training category. We note that the ANOVA is asymptotically equivalent to the Kruskal-Wallis test. Then a two-way ANOVA was conducted to examine for differences in cover ranks considering both life-form and training category. The cover ranks were normally distributed by training category except for the heavy training sites. 


\section{Results}

Highest understory plant species diversity occurred in light training sites and reference areas which also contained the oldest trees (Table 2). However, richness was also high in moderate training and remediation areas. Both diversity and understory plant cover were lowest in the heavy training areas which did not have a developed overstory. The moderate training areas had about two-thirds the amount of understory cover as did reference, light training, and remediation sites, and understory cover for those three areas was not distinguishable. Tree cover was highest in reference and light training areas, absent in heavy training areas, and very low in moderate training and remediation sites (Table 2).

A total of 134 understory plant species representing 36 families were identified in different training regimes at Fort Benning (see Appendix A). Many species had high variation in cover over all the training types, and we were unable to separate training types by species using multivariate analyses. Most species contributed an average of less than $1 \%$ cover. Little bluestem (Andropogon scoparius) had the highest mean cover $(2.64 \%)$. Three awn grass (Aristida oliganthum) was the only species that occurred in all five training categories. Eight species were found only in reference and light training sites. Some species were found in only one training type: 11 in reference sites, 13 in light training, 14 in moderate training, and 4 in remediated sites. However, there were no species that occurred only in heavy training sites. Moderate training supported eight species which also occurred in sites with heavy training.
Families that contributed greater than $1 \%$ cover to the understory also differed by training category (Fig. 3). Grasses (Graminae) had the most cover for all categories. The heavy training had very little grass cover (2\%), but grass cover exceeded $45 \%$ for moderate and reference areas and was greater than 75\% for remediated areas. The reference sites had more than $30 \%$ cover of composites (Asteraceae) compared to $17 \%$ composite cover for light training areas and less than $5 \%$ for other training categories. Light training areas had the broadest taxonomic representation with 10 families contributing more than $1 \%$ cover as compared to one family (Graminae) for heavy training, four for moderate training, and six each for the reference and remediated sites.

Raunkiaer's life-form accounted for some differences between disturbances (Fig. 4). Over all samples, 12 species were Chamaephytes (plants with buds that are $0.1-0.5 \mathrm{M}$ above ground), 38 species were Cryptophytes (plants with below ground dormant tissue), 32 species were Hemicryptophytes (plants with buds that at the ground surface), 34 species were Phanerophytes (trees or shrubs with buds greater then $0.5 \mathrm{~m}$ above ground), and 18 species were Therophytes (annuals) (see Appendix A). The frequency distribution of these species by life-form and training intensity is shown in Table 3. Crypotophyes were the most frequent group of species for reference, moderate, heavy, and remediation areas. In contrast, Phanerophytes were the most frequent life-form for light training areas. Therophytes (annuals) were least frequent for reference and light training areas, whereas Chamaephytes were least frequent for moderate and remediation sites. Heavy

Table 2

Mean and standard deviation (in parentheses) of vegetation characteristics of the different training intensities and remediated plots

\begin{tabular}{|c|c|c|c|c|c|}
\hline \multirow[t]{2}{*}{ Characteristic } & \multicolumn{5}{|c|}{ Training category } \\
\hline & Reference & Light & Moderate & Heavy & Remediation \\
\hline Understory species richness & 82 & 95 & 78 & 16 & 69 \\
\hline Percent understory cover & $\begin{array}{l}67.00 \\
(10.79)\end{array}$ & $\begin{array}{l}67.87 \\
(12.86)\end{array}$ & $\begin{array}{l}44.40 \\
(18.21)\end{array}$ & $\begin{array}{l}4.73 \\
(4.50)\end{array}$ & $\begin{array}{l}67.00 \\
(17.24)\end{array}$ \\
\hline Percent tree cover & $\begin{array}{l}36.19 \\
(4.01)\end{array}$ & $\begin{array}{l}26.10 \\
(5.59)\end{array}$ & $\begin{array}{l}0.53 \\
(0.92)\end{array}$ & $\begin{array}{l}0.00 \\
(0.00)\end{array}$ & $\begin{array}{l}1.92 \\
(2.72)\end{array}$ \\
\hline Stand age (years) & $\begin{array}{l}56.50 \\
(24.83)\end{array}$ & $\begin{array}{l}83.67 \\
(22.40)\end{array}$ & $\mathrm{NA}^{\mathrm{a}}$ & $\mathrm{NA}^{\mathrm{a}}$ & $7^{\mathrm{b}}$ \\
\hline
\end{tabular}

\footnotetext{
${ }^{a}$ NA: not applicable because there were no overstory trees in the plots
}

$\mathrm{b}$ Tree age was estimated from planting history. 


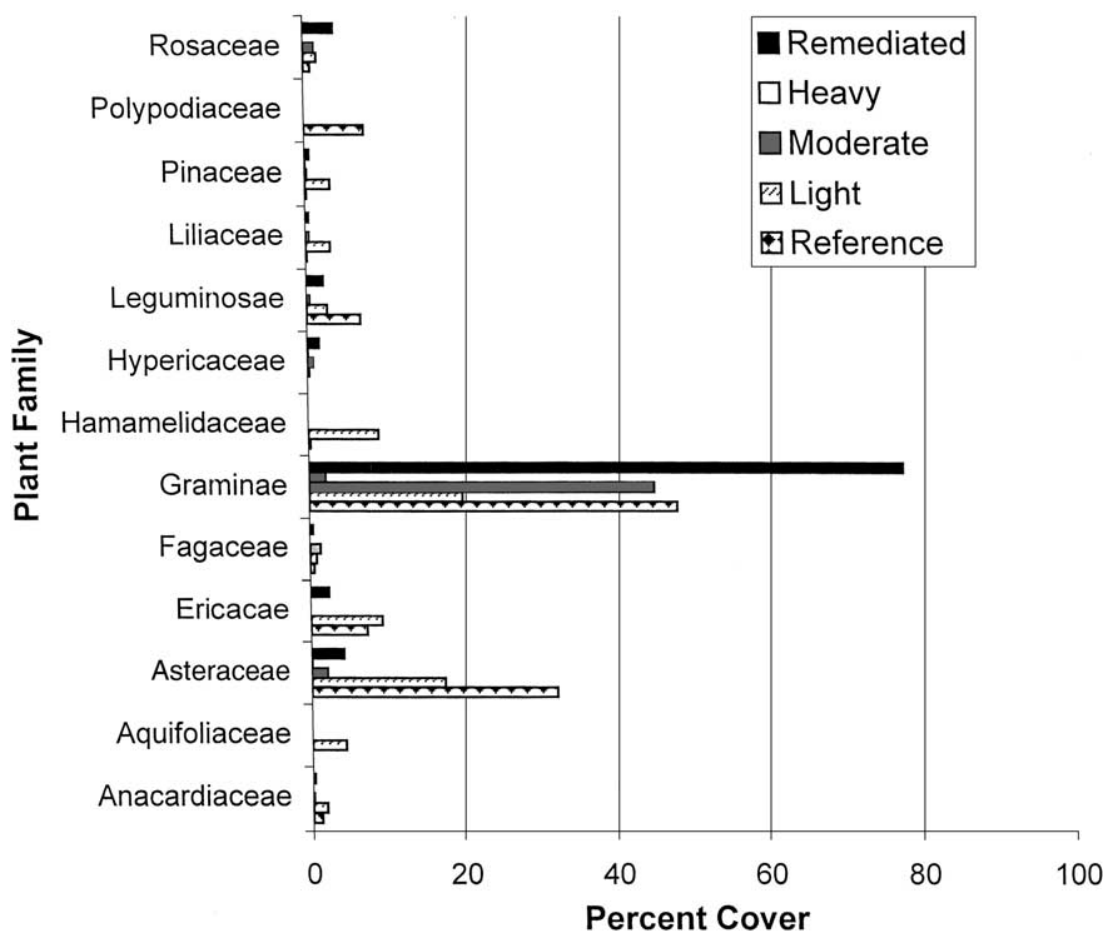

Fig. 3. Percent cover of plant families (for those families with greater than $1 \%$ cover) by training category.

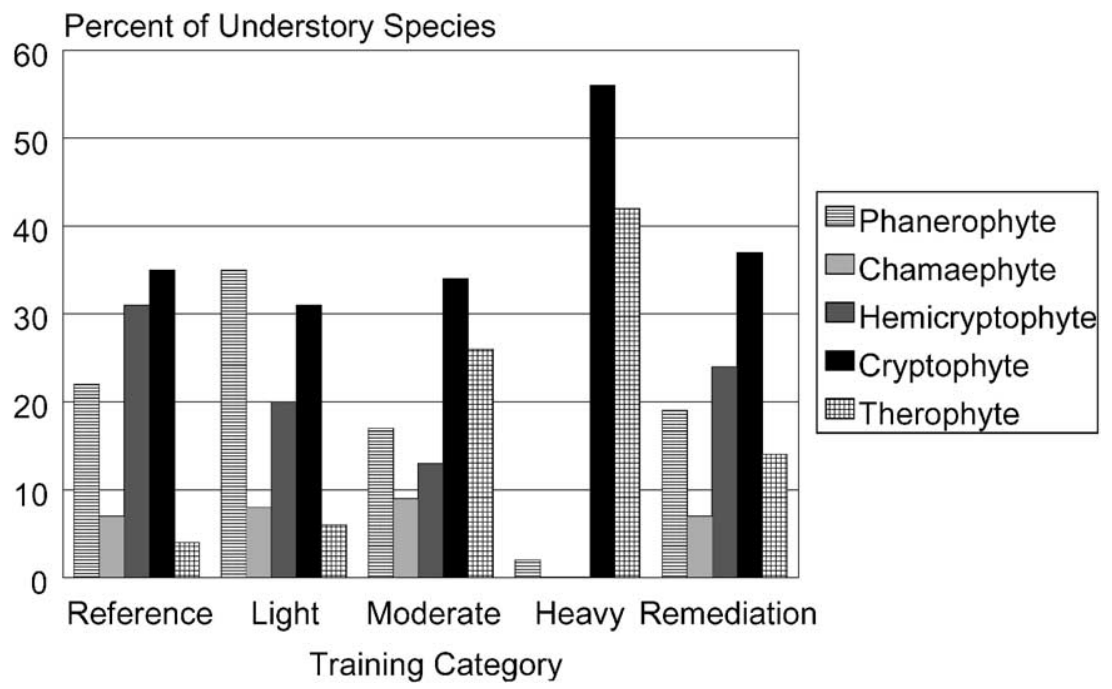

Fig. 4. Life-form distribution by training categories for understory species. 
Table 3

Percent of understory species representing major life-forms in training categories (repetitions of species can occur across plots)

\begin{tabular}{lcccccc}
\hline Life-form & \multicolumn{3}{l}{ Training category (number of plots) } & & $\begin{array}{l}\text { Total number of times that species } \\
\text { of each form were encountered }\end{array}$ \\
\cline { 2 - 6 } & $\begin{array}{l}\text { Reference } \\
(15)\end{array}$ & $\begin{array}{l}\text { Light } \\
(15)\end{array}$ & $\begin{array}{l}\text { Moderate } \\
(15)\end{array}$ & $\begin{array}{l}\text { Heavy } \\
(15)\end{array}$ & $\begin{array}{l}\text { Remediation } \\
(10)\end{array}$ & \\
\hline Phanerophyte & 22 & 35 & 17 & 2 & 19 & 339 \\
Chamaephyte & 7 & 8 & 9 & 0 & 7 & 105 \\
Hemicryptophyte & 31 & 20 & 13 & 0 & 24 & 309 \\
Cryptophyte & 35 & 31 & 34 & 56 & 37 & 165 \\
Therophyte & 4 & 6 & 26 & 42 & 14 & 1408 \\
$\begin{array}{l}\text { Total number of times } \\
\quad\end{array}$ & 429 & 436 & 268 & 48 & 227 & \\
$\quad \begin{array}{l}\text { that species of each } \\
\text { form were encountered }\end{array}$ & & & & & & \\
\hline
\end{tabular}

Table 4

Comparisons of the frequency of understory plants in vegetation cover classes by life-form for five training categories using the Cochran-Mantel-Haenszel statistic (based on rank scores) and single-factor ANOVA

\begin{tabular}{llllll}
\hline Statistic & \multicolumn{2}{l}{ Training category (number of plots) } & & \\
\cline { 2 - 6 } & Reference (15) & Light (15) & Moderate (15) & Heavy (15) & Remediation (10) \\
\hline $\begin{array}{lllll}\text { Cochran-Mantel-Haenszel } \\
\text { Statistic }\end{array}$ & 47.39 & 57.959 & 76.484 & 75.738 & 18.141 \\
$F$ & - & - & - & - & - \\
$P$ & 0.001 & 0.001 & 0.001 & 0.001 & .0001 \\
ANOVA & & & & 0.98 & 11.28 \\
$F$ & 6.75 & 7.28 & 13.92 & NS & 0.0001 \\
$P$ & 0.0001 & 0.0001 & 0.0001 & & \\
\hline
\end{tabular}

training sites supported no Chamaephytes or hemicrytophyes.

Differences in the ranks of the cover scores for all life-forms found in the plots (i.e. zeroes were eliminated) was examined using ANOVA and the CochranMantel-Haenszel statistic (Table 4). All training types had fewer species in the higher cover classes than in categories with low cover. There were significant differences in cover ranks by life-forms within reference, light, moderate, and remediation sites, but not within heavy sites. The lack of difference in the heavy training sites likely reflects the paucity of plants found there. The two-way ANOVA revealed significant differences in cover ranks considering both life-form and training intensity (Table 5).

Depth of the soil A horizon, which is used as a measure of impact of military training, differed significantly between categories of training intensity $\left(F_{4.65}=24.3, P<0.001\right)$. Light and reference areas had the greatest depth and also the highest variability
Table 5

Two-way analysis of variance of the plant frequency by life-form and training category when reference, light, moderate and heavy training are considered

\begin{tabular}{llrl}
\hline & Degrees of freedom & \multicolumn{1}{l}{$F$} & \multicolumn{1}{l}{$P$} \\
\hline Training category & 3 & 7.50 & .0001 \\
Life-form & 4 & 16.15 & .0001 \\
Interaction & 7 & 12.44 & .0001 \\
\hline
\end{tabular}

(Fig. 5). Depth of the A horizon for heavy, moderate, and remediated sites was consistently small.

\section{Discussion}

Except for distinguishing heavy training areas, these data suggest that neither understory cover nor plant diversity are useful indicators of past training. This inability to discriminate may have occurred because 


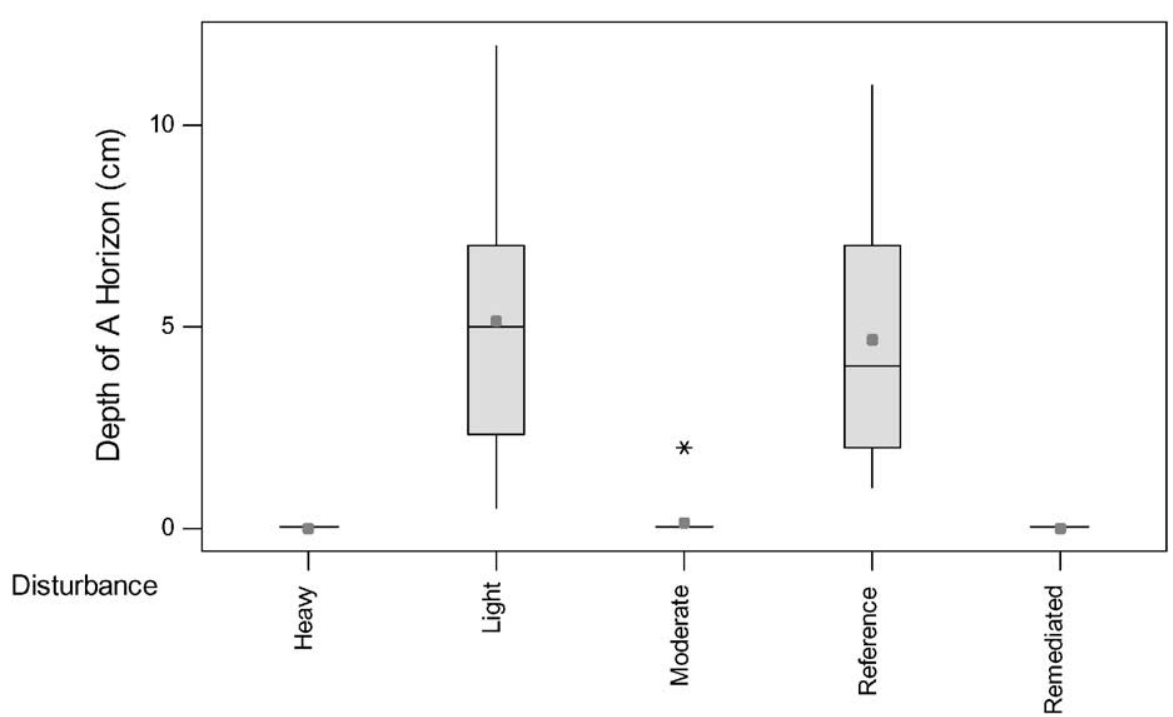

Fig. 5. Boxplot of the depth of the A soil horizon by training intensity type. The bottom and top edges of the box are located at the sample 25th and 75th percentiles. The center horizontal line occurs at the sample median. Means are indicated by solid squares; an outlier value is indicated by an asterisk.

the training areas differed in canopy cover with the light and reference areas being the only ones having significant overstory cover. In those stands, the average age of the trees was 56 years for the reference sites and 83 years for lightly trained sites suggesting it had been at least five-eight decades since a disturbance large enough to induce tree replacement had occurred. However, the influence of canopy cover on understory diversity and cover was not strong. Neither moderate nor remediated sites had an established tree canopy; yet they supported 78 and 69 understory species, respectively, compared to 82 and 95 species for reference and light training areas.

Furthermore, understory cover of remediated areas was equivalent to that of reference and light training sites. Moderate sites averaged 44\% understory cover, about two-thirds of that in light, remediated, and reference sites, suggesting that recovery still had to be achieved. Understory species richness and percent cover were quite low for the heavily-used training areas probably because most plants had been removed by repeated tank traffic.

The high diversity and large variation in understory cover of longleaf pine forests and reestablishing vegetation provided a challenge in the use of understory species to distinguish between training impacts in longleaf pine stands (see Appendix A). It was not surprising that little bluestem (Andropogon scoparius) contributed the highest mean cover over all sites, for it is a characteristic plant of longleaf pine forests (Dobrowolski et al., 1992; Kirkman et al., 2000). Species that were only identified from one type of training area sometimes were helpful in identifying characteristics of such sites. For example, bracken fern (Pteridium aquilinum) was only found in reference sites and is a typical plant of old growth longleaf pine stands. Prickly pear (Opuntia compressa) was only found in moderately disturbed sites and can likely withstand the stressful conditions of such sites. The high variability in understory vegetation cover over training categories probably led to the lack of separation by training category by species which required analyses based upon groupings of species into life-forms and families, which are measures of structure and composition (respectively).

In contrast to considering diversity and cover of all species, life-form offered a more effective indicator of past disturbances. Frequency of life-form occurrence distinguishes between military disturbance. Trees and shrubs (Phanerophytes), which may be less affected by foot soldier traffic than other life-forms, dominated cover in light training areas. However, in an extensive 
literature review of foot traffic impacts on vegetation, shrubs and trees suffered the longest lasting decrease (Yorks et al., 1997). Our analysis suggested that foot traffic impact on trees and shrubs may not be as intense as on other life-forms. This difference between duration and intensity of disturbance impacts is a necessary distinction (White and Pickett, 1985). Cryptophytes dominate in all other training categories possibly because they are common in the flora due to their ability to withstand ground fires, the natural disturbance of longleaf pine forests. Plants with underground buds are possibly the only vegetation able to withstand heavy tank traffic. In contrast, Therophytes, which are also found in the heavy training areas, likely seeded into sites after mechanized training ceased. Chamaephytes do not contribute more than $1 \%$ cover for any training treatment possibly because they are uncommon in the longleaf pine flora and because they are susceptible to all types of traffic.

Previous studies document that life-form reflects impacts following volcanic eruption, grazing, tree thinning, water additions, and soil disturbance (Adams et al., 1987; McIntyre et al., 1995; Stohlgren et al., 1999). In a comparison of treatments designed to reduce hardwood in-growth in longleaf pine forests, fire resulted in the greatest increase in understory species richness and herbaceous groundcover plant densities as compared to herbicide treatments (Provencher et al., 2001). This difference is likely attributed to the fire allowing the survival of plants with their buds below the surface much as dismounted training allows Cryptophytes to survive. Furthermore, life-form changed in the understory after thinning in Douglas fir (Pseudotsuga menziesii) plantations (Thomas et al., 1999). Studies from the inner Mongolia Plateau report that life-form is a greater determinant of ecosystem processes than is species richness (Bai et al., 2001).

Plant families are also a useful way to group understory vegetation to reflect differences in training regimes. Of those families that contribute more than one percent cover, light training areas had the highest diversity with 11 families represented whereas heavy training areas had only one family present. Anacardiaceae was the most abundant family in the light training sites (possible because foot soldiers may have avoided poison ivy, one of the common representatives of this family, giving it a competitive advantage over other species that were more readily tramped upon).
Both remediated and reference sites each contained six families with greater than $1 \%$ cover, but three of these families were not the same. Ferns (Polypodiaceae) and, in particular, bracken fern (Pteridium aquilinum) were distinct to reference sites and can be assumed to be an indicator of the absence of military disturbance.

Graminae was the only family common to all training types. Yorks et al. (1997) report from their literature review of foot traffic impacts that graminoids were found to be most resistant. Grasses contributed very little cover in the heavily trained sites but provided more than $70 \%$ cover to the remediated sites. It is not surprising that remediated sites had such high cover of grasses, for recovery efforts of these areas included planting grass seed. The relevant management question is: does such planting bring impacted sites closer to the vegetative characteristic of naturally revegetating sites? We found no family that was distinct to remediated sites. Except for the low percentage of trees and shrubs, life-form distribution of remediated sites is similar to that of both reference and lightly trained sites with Cryptophytes being well represented (Fig. 4). Thus, this analysis suggests that the remediated sites are moving along the pathway toward established vegetation much like that of the reference or lightly trained areas.

Depth of the soil A horizon offers a means independent of observation and vegetative measures to distinguish between the impacts due to military training. The fact the A horizon depth for sites that experienced dismount traffic is not distinct from the reference sites suggests that foot soldier traffic has relatively little impact on the physical conditions of the longleaf pine understory. Yet, the increased percent of trees and shrubs species in the light training areas versus the reference sites cannot be explained by soil properties but is more likely a result of the movement of foot soldiers through the forest.

\section{Conclusions}

We hypothesized that understory diversity and cover sampled from an anthropogenic disturbance gradient within the longleaf pine forests would reveal significant compositional and structural differences that occurred as a result of military training intensity. The confirmation of life-form distribution and plant 
family cover as distinguishing features suggests that monitoring programs for longleaf pine forests should include understory vegetation as an ecological indicator. These metrics can serve as surrogate measures of disturbance to the longleaf pine system. Both life-form distribution and plant family cover appear to be useful ways to group the large number of species which occur in the understory of these longleaf pine forests.

Indicators of disturbance that are used for resource management need to be easy to measure, sensitive to stresses, and predictable as to how they respond to stress (Cairns et al., 1993; Stewart and Loar, 1994, Dale and Beyeler, 2001). Selecting indicators for the understory of longleaf pine forests is complicated by the high species diversity. Field classification of understory plants according to life-form and family is relatively straightforward compared to species identification. Both of these attributes are relatively easy and time efficient to measure and interpret. Thus, we recommend that the suite of indicators used for monitoring longleaf pine ecosystems include these metrics.

\section{Acknowledgements}

Tom Ashwood, John Brent, Theresa Davo, Patty Kosky, Lisa Olsen, Pete Swiderek, and Waterways Experiment Station provided assistance with this study. Reviews of an earlier draft of the paper by Chuck Garten and Aaron Peacock were quite helpful. Larry Pounds assisted with taxonomic identification. The project was funded by a contract from the Strategic Environmental Research and Development Program (SERDP), Ecosystem Management Program (SEMP) to Oak Ridge National Laboratory (ORNL). Oak Ridge National Laboratory is managed by the University of Tennessee-Battelle LLC. for the US Department of Energy under contract DE-AC05-00OR22725 .

\section{Appendix A}

Characteristics of understory species found in longleaf pine forests at Fort Benning, GA.

\begin{tabular}{|c|c|c|c|c|c|c|c|c|}
\hline Botanical name & Family & \multicolumn{2}{|c|}{$\begin{array}{l}\text { Raunkiaer life-form } \\
\text { (as discussed by Kershaw } \\
\text { and Looney, 1985) }\end{array}$} & Growth-form & Cover & S.D & Common name & $\begin{array}{l}\text { Location by impact } \\
(\mathrm{R}=\text { reference }, \mathrm{L}=\text { light, } \\
\mathrm{M}=\text { moderate }, \mathrm{H}=\text { heavy, } \\
\mathrm{D}=\text { remediated })\end{array}$ \\
\hline Agalinis purpurea & Scrophulariaceae & Therophyte & & Forb & 0.17 & 0.45 & Gererdia & LMD \\
\hline Albizia julibrissin & Leguminosae & Phanerophyte & Deciduous & Tree & 0.01 & 0.12 & Silk tree & $\mathrm{L}$ \\
\hline Ambrosia artemisiifolia & Asteraceae & Therophyte & & Forb & 0.01 & 0.12 & Annual ragweed & M \\
\hline Andropogon scoparius & Graminae & Cryptophyte & Geophyte & Graminoid & 2.64 & 2.78 & Little bluestem & RLMH \\
\hline Andropogon ternarius & Graminae & Cryptophyte & Geophyte & Graminoid & 1.20 & 2.04 & Splitbeard bluestem & RLD \\
\hline Aristida oligantha & Graminae & Cryptophyte & Geophyte & Graminoid & 0.86 & 1.72 & Threeawn grass, wire grass & RLMHD \\
\hline Aristida purpurascens & Graminae & Cryptophyte & Geophyte & Graminoid & 1.27 & 2.07 & Arrowfeather threeawn grass & RMHD \\
\hline Aster concolor & Asteraceae & Cryptophyte & Geophyte & Forb & 0.26 & 0.63 & Eastern silver aster & $\mathrm{R}$ \\
\hline Aster dumosus & Asteraceae & Cryptophyte & Geophyte & Forb & 0.37 & 0.71 & Rice button aster & RLD \\
\hline Aster patens & Asteraceae & Cryptophyte & Geophyte & Forb & 0.06 & 0.23 & Spreading aster ${ }^{\mathrm{a}}$ & RLMD \\
\hline Aster tortifolius & Asteraceae & Cryptophyte & Geophyte & Forb & 0.77 & 1.49 & White-topped aster & RLMD \\
\hline Bulbostylis ciliatifolia & Cyperaceae & Therophyte & & Forb & 0.16 & 0.71 & Bulbos rush ${ }^{\mathrm{a}}$ & M \\
\hline Cacalia lanceolata & Asteraceae & Hemicryptophyte & Rosette & Forb & 0.04 & 0.20 & Indian-plantain & $\mathrm{R}$ \\
\hline Cacalia muhlenbergii & Asteraceae & Hemicryptophyte & Rosette & Forb & 0.14 & 0.43 & Great Indian- plantain & $\mathrm{RD}$ \\
\hline Carya tomentosa & Juglandaceae & Phanerophyte & Deciduous & Tree & 0.14 & 0.55 & Mockernut hickory & LD \\
\hline Cassia nictitans & Leguminosae & Therophyte & & Forb & 0.89 & 1.29 & Partridge pea & RLMD \\
\hline Cenchrus longispinus & Graminae & Therophyte & & Forb & 0.20 & 0.77 & Sandspurs & M \\
\hline Conyza canadensis & Asteraceae & Therophyte & & Forb & 0.46 & 0.85 & Horseweed & MHD \\
\hline Coreopsis major & Asteraceae & Cryptophyte & Geophyte & Forb & 0.24 & 0.65 & Greater tickseed & $\mathrm{R}$ \\
\hline Crataegus flava & Rosaceae & Phanerophyte & Deciduous & Tree & 0.47 & 1.10 & Yellow hawthorne & RLMD \\
\hline Crataegus pulcherrima & Rosaceae & Phanerophyte & Deciduous & Tree & 0.06 & 0.38 & Handsome hawthorne $\mathrm{a}^{\mathrm{a}}$ & LD \\
\hline Crataegus spathulata & Rosaceae & Phanerophyte & Deciduous & Tree & 0.01 & 0.12 & Little hop hawthorne & $\mathrm{R}$ \\
\hline Croton glandulosus & Euprorbiaceae & Therophyte & & Forb & 0.06 & 0.23 & Croton & MH \\
\hline Cynodon dactylon & Graminae & Cryptophyte & Geophyte & Graminoid & 0.61 & 1.54 & Bermuda grass & MH \\
\hline Desmodium sp. & Leguminosae & Cryptophyte & Geophyte & Forb & 0.49 & 0.93 & Ticktrefoil & RLM \\
\hline Desmodium ciliare & Leguminosae & Cryptophyte & Geophyte & Forb & 0.24 & 0.60 & Hairy smallleaf ticktrefoil & RL \\
\hline Desmodium floridanum & Leguminosae & Cryptophyte & Geophyte & Forb & 0.10 & 0.35 & Florida ticktrefoil & $\mathrm{L}$ \\
\hline Desmodium lineatum & Leguminosae & Cryptophyte & Geophyte & Forb & 0.37 & 0.80 & Linear ticktrefoil ${ }^{\mathrm{a}}$ & RLM \\
\hline Desmodium strictum & Leguminosae & Cryptophyte & Geophyte & Forb & 0.11 & 0.40 & Pinebarren ticktrefoil & $\mathrm{L}$ \\
\hline Dichanthelium aciculare & Graminae & Cryptophyte & Geophyte & Forb & 0.04 & 0.27 & Needleleaf rosetta grass & $\mathrm{D}$ \\
\hline Dichanthelium oligosanthes & Graminae & Cryptophyte & Geophyte & Forb & 0.63 & 1.22 & Bound rosetta grass ${ }^{\mathrm{a}}$ & RLMD \\
\hline
\end{tabular}


Appendix A. (Continued)

\begin{tabular}{|c|c|c|c|c|c|c|c|c|}
\hline Botanical name & Family & \multicolumn{2}{|c|}{$\begin{array}{l}\text { Raunkiaer life-form } \\
\text { (as discussed by Kershaw } \\
\text { and Looney, 1985) }\end{array}$} & Growth-form & Cover & SD & Common name & $\begin{array}{l}\text { Location by impact } \\
(\mathrm{R}=\text { reference, } \mathrm{L}=\text { light, } \\
\mathrm{M}=\text { moderate } \mathrm{H}=\text { heavy, } \\
\mathrm{D}=\text { remediated })\end{array}$ \\
\hline Dichanthelium sabulorum & Graminae & Cryptophyte & Geophyte & Forb & 1.11 & 1.86 & Hemlock rosetta grass & RLMD \\
\hline Digitaria violascens & Graminae & Cryptophyte & Geophyte & Forb & 0.39 & 1.07 & Crabgrass & MHD \\
\hline Diodea teres & Graminae & Therophyte & & Forb & 0.81 & 1.27 & Poorjoe & LMH \\
\hline Diospyros virginiana & Ebenaceae & Phanerophyte & Deciduous & Tree & 1.29 & 1.44 & Common persimmon & RLMD \\
\hline Elephantopus tomentosus & Asteraceae & Hemicryptophyte & Partial rosette & Forb & 0.26 & 0.94 & Devils grandmother & $\mathrm{R}$ \\
\hline Eragrostis curvula & Graminae & Cryptophyte & Geophyte & Graminoid & 0.09 & 0.72 & Weeping lovegrass & M \\
\hline Eragrostis capillaris & Graminae & Therophyte & & Graminoid & 1.00 & 2.11 & Slender lovegrass & LMD \\
\hline Eragrostis refracta & Graminae & Cryptophyte & Geophyte & Graminoid & 0.64 & 1.65 & Coastal lovegrass & MHD \\
\hline Erianthus contortus & Graminae & Cryptophyte & Geophyte & Graminoid & 0.16 & 0.61 & Sugar cane & $\mathrm{L}$ \\
\hline Eupatorium album & Asteraceae & Hemicryptophyte & Proto & Forb & 0.41 & 0.89 & White thoroughwort & RLMD \\
\hline Eupatorium aromaticum & Asteraceae & Hemicryptophyte & Proto & Forb & 0.37 & 1.02 & Aromatic thoroughwort & RL \\
\hline Eupatorium capillifolium & Asteraceae & Hemicryptophyte & Proto & Forb & 0.64 & 1.17 & Small dogfennel & RLM \\
\hline Eupatorium coelestinum & Asteraceae & Hemicryptophyte & Proto & Forb & 0.03 & 0.17 & Mistflower & $\mathrm{R}$ \\
\hline Eupatorium hyssopifolium & Asteraceae & Hemicryptophyte & Proto & Forb & 0.69 & 1.28 & Hyssopleaf thoroughwort & RLMD \\
\hline Euphorbia corollata & Euphorbiaceae & Hemicryptophyte & Proto & Forb & 0.16 & 0.40 & Flowering spurge & RLD \\
\hline Froelichia gracilis & Amaranthaceae & Therophyte & & Forb & 0.10 & 0.35 & Cottonweed & $\mathrm{MH}$ \\
\hline Galium hispidulum & Rubiaceae & Chamaephytes & Active & Forb & 0.01 & 0.12 & Coastal beardstraw & $\mathrm{L}$ \\
\hline Gaylussacia frondosa & Ericacae & Phanerophyte & Deciduous & Tree & 0.06 & 0.29 & Dangleberry & $\mathrm{R}$ \\
\hline Gelsemium sempervirens & Loganiaceae & Chamaephytes & Active & Vine & 0.07 & 0.26 & Yellow Jasmine & LM \\
\hline Gymnopogon ambiguus & Graminae & Cryptophyte & Geophyte & Grass & 0.17 & 0.45 & Beard grass & RLD \\
\hline Haplopappus divaricatus & Asteraceae & Therophyte & & Forb & 0.44 & 0.83 & Haplopappus & LMHD \\
\hline Helianthus longifolius & Asteraceae & Cryptophyte & Geophyte & Forb & 0.13 & 0.68 & Longleaf sunflower & $\mathrm{D}$ \\
\hline Heterotheca graminifolia & Asteraceae & Hemicryptophyte & Partical Rossett & Forb & 2.13 & 2.78 & Narrowleaf silkgrass & RLD \\
\hline Heterotheca subaxillaris & Asteraceae & Therophyte & & Forb & 0.04 & 0.20 & Annual silkgrass ${ }^{\mathrm{a}}$ & M \\
\hline Heterotheca gossypina & Asteraceae & Hemicryptophyte & Partial Rosette & Forb & 0.09 & 0.44 & Hairy silkgrass ${ }^{\mathrm{a}}$ & $\mathrm{L}$ \\
\hline Heterotheca mariana & Composite & Hemicryptophyte & Partial Rosette & Forb & 0.20 & 0.60 & Erect silkgrass ${ }^{\mathrm{a}}$ & RL \\
\hline Hieracium gronovii & Asteraceae & Cryptophyte & Geophyte & Forb & 0.03 & 0.17 & Queendevil & $\mathrm{L}$ \\
\hline Hypericum gentianoides & Hypericaceae & Therophyte & & Forb & 0.66 & 1.06 & Pineweed & LMHD \\
\hline Hypericum hypericoides & Hypericaceae & Phanerophyte & Deciduous & Forb & 0.34 & 0.88 & St. Andrew's cross & LMD \\
\hline Ilex glabra & Aquifoliaceae & Phanerophyte & Evergreen & Shrub & 0.17 & 1.06 & Inkberry & $\mathrm{L}$ \\
\hline Ipomoea pandurata & Convolvulaceae & Chamaephytes & Active & Vine & 0.07 & 0.31 & Man of the Earth & M \\
\hline Ipomoea purpurea & Convolvulaceae & Therophyte & & Forb & 0.01 & 0.12 & Common morning glory & $\mathrm{D}$ \\
\hline Lechea minor & Cistaceae & Hemicryptophyte & Proto & Forb & 0.17 & 0.48 & Thyme leaf pinweed & RLMD \\
\hline Lechea villosa & Cistaceae & Hemicryptophyte & Proto & Forb & 0.17 & 0.54 & Hairy pinweed & MD \\
\hline Lespedeza cuneata & Leguminosae & Hemicryptophyte & Proto & Forb & 0.24 & 0.77 & Chinese lespodeza & MD \\
\hline Lespedeza hirta & Leguminosae & Hemicryptophyte & Proto & Forb & 0.37 & 0.76 & Hairy lespodeza & RLMD \\
\hline Lespedeza repens & Leguminosae & Hemicryptophyte & Proto & Forb & 0.19 & 0.57 & Creeping lespodeza & MD \\
\hline Lespedeza stuevei & Leguminosae & Hemicryptophyte & Proto & Forb & 0.23 & 0.57 & Tall lespodeza & RLMD \\
\hline Liatris elegans & Asteraceae & Cryptophyte & Geophyte & Forb & 0.21 & 0.59 & Pinkscale gayfeather & RL \\
\hline Liatris graminifolia & Asteraceae & Cryptophyte & Geophyte & Forb & 0.17 & 0.45 & Blazing star & RL \\
\hline Liatris tenuafolia & Asteraceae & Cryptophyte & Geophyte & Forb & 0.11 & 0.36 & Blazing star & $\mathrm{RM}$ \\
\hline Lichens & & & & Lichens & 0.61 & 1.69 & Lichen & MD \\
\hline Liquidambar stryraciflua & Hamamelidaceae & Phanerophyte & Deciduous & Tree & 0.61 & 1.76 & Sweet gum & RL \\
\hline Lithospermum caroliniense & Boraginaceae & Hemicryptophyte & Proto & Forb & 0.01 & 0.12 & Puccoon & $\mathrm{M}$ \\
\hline Lobelia puberula & Campanulaceae & Hemicryptophyte & Proto & Forb & 0.01 & 0.12 & Downy lobelia & $\mathrm{L}$ \\
\hline Mollugo verticillata & Aizoceae & Therophyte & & Forb & 0.01 & 0.12 & Indian chickweed & M \\
\hline moss & & & & Mosses & 0.66 & 1.73 & Moss & LMD \\
\hline Muhlenbergia expansa & Graminae & Cryptophyte & Geophyte & Forb & 0.11 & 0.55 & Muhly & $\mathrm{RD}$ \\
\hline Myrica cerifera & Myricaceae & Phanerophyte & Deciduous & Shrub & 0.19 & 0.77 & Southern bayberry & $\mathrm{L}$ \\
\hline Opuntia compressa & Cactaceae & Hemnicrytophye & Rosette & Forb & 0.03 & 0.17 & Prickly pear & M \\
\hline Paronychia herniarioides & Caryophyllaceae & Therophyte & & Forb & 0.03 & 0.17 & Coastal Plain nailwort & M \\
\hline Paspalum notatum & Graminae & Cryptophyte & Geophyte & Forb & 1.33 & 2.50 & Bahiagrass & M \\
\hline Passifloria incarnata & Passifloraceae & Hemicryptophyte & Proto & Vine & 0.01 & 0.12 & Maypops & $\mathrm{M}$ \\
\hline Petalostemum pinnatum & Leguminosae & Hemicryptophyte & Proto & Forb & 0.10 & 0.39 & Summer-farewell & RL \\
\hline Pinus echinata & Pinaceae & Phanerophyte & Evergreen & Tree & 0.23 & 0.85 & Shortleaf pine & LH \\
\hline Pinus palustris & Pinaceae & Phanerophyte & Evergreen & Tree & 0.71 & 1.31 & Longleaf pine & RLMD \\
\hline Pinus taeda & Pinaceae & Phanerophyte & Evergreen & Tree & 0.14 & 0.62 & Loblolly pine & RLD \\
\hline Polypremum procumbens & Loganiaceae & Cryptophyte & Geophyte & Forb & 0.24 & 0.62 & Juniper leaf & LMHD \\
\hline Prunus sp. 1 & Rosaceae & Phanerophyte & Deciduous & Tree & 0.14 & 0.62 & Plum & MD \\
\hline Prunus serotina & Rosaceae & Phanerophyte & Deciduous & Tree & 0.03 & 0.17 & Black cherry & LD \\
\hline Prunus sp. 2 & Rosaceae & Phanerophyte & Deciduous & Tree & 0.01 & 0.12 & Plum & $\mathrm{M}$ \\
\hline Pteridium aquilinum & Polypodiaceae & Cryptophyte & Geophyte & Forb & 0.64 & 1.73 & Western brackenfern & $\mathrm{R}$ \\
\hline Quercus incana & Fagaceae & Phanerophyte & Evergreen & Tree & 0.14 & 0.62 & Blue jack oak & RLD \\
\hline Quercus laevis & Fagaceae & Phanerophyte & Deciduous & Tree & 0.10 & 0.51 & Turkey oak & RL \\
\hline Quercus laurifolia & Fagaceae & Phanerophyte & Deciduous & Tree & 0.10 & 0.42 & Laurel oak & RLM \\
\hline
\end{tabular}


Appendix A. (Continued)

\begin{tabular}{|c|c|c|c|c|c|c|c|c|}
\hline Botanical name & Family & \multicolumn{2}{|c|}{$\begin{array}{l}\text { Raunkiaer life-form } \\
\text { (as discussed by Kershaw } \\
\text { and Looney, 1985) }\end{array}$} & Growth-form & \multicolumn{2}{|l|}{ Cover } & Common name & $\begin{array}{l}\text { Location by impact } \\
(\mathrm{R}=\text { reference, } \mathrm{L}=\text { light, } \\
\mathrm{M}=\text { moderate }, \mathrm{H}=\text { heavy, } \\
\mathrm{D}=\text { remediated })\end{array}$ \\
\hline Quercus margaretta & Fagaceae & Phanerophyte & Deciduous & Tree & 0.13 & 0.80 & Shrubby post oak & RM \\
\hline Quercus marilandica & Fagaceae & Phanerophyte & Deciduous & Tree & 0.81 & 1.34 & Blackjack oak & RL \\
\hline Quercus nigra & Fagaceae & Phanerophyte & Deciduous & Tree & 0.24 & 0.73 & Water oak & RLMD \\
\hline Quercus shumardii & Fagaceae & Phanerophyte & Deciduous & Tree & 0.03 & 0.17 & Swamp red oak & $\mathrm{RM}$ \\
\hline Quercus stellata & Fagaceae & Phanerophyte & Deciduous & Tree & 0.10 & 0.46 & Post oak & $\mathrm{L}$ \\
\hline Rhus aromatica & Anacardiaceae & Phanerophyte & Deciduous & Shrub & 0.16 & 0.53 & Fragrant sumac & MD \\
\hline Rhus copallina & Anacardiaceae & Phanerophyte & Deciduous & Shrub & 1.00 & 1.39 & Flameleaf sumac & RLM \\
\hline Rhynchosia reniformis & Leguminosae & Hemicryptophyte & Proto & Forb & 0.50 & 0.76 & Dollar leaf & RL \\
\hline Rubus cuneifolius & Rosaceae & Phanerophyte & Deciduous & Shrub & 1.24 & 1.58 & Sand blackberry & RLMD \\
\hline Rubus trivialis & Rosaceae & Chamaephytes & Active & Shrub & 0.87 & 1.50 & Dewberry & RLMD \\
\hline Ruellia caroliniensis & Acanthaceae & Hemicryptophyte & Partial rosette & Forb & 0.03 & 0.17 & Carolina wild petunia & $\mathrm{R}$ \\
\hline Sassafras albidum & Lauraceae & Phanerophyte & Deciduous & Tree & 0.34 & 0.92 & Sassafras & RLD \\
\hline Schrankia microphylla & Leguminosae & Phanerophyte & Deciduous & Tree & 0.06 & 0.23 & Sensitive plant & RL \\
\hline Seymeria pectinata & Scrophulariaceae & Therophyte & & Forb & 0.10 & 0.49 & Piedmont blacksenna & $\mathrm{L}$ \\
\hline Smilax bona-nox & Liliaceae & Chamaephytes & Active & Forb & 0.20 & 0.91 & Saw greenbriar & RLM \\
\hline Smilax glauca & Liliaceae & Chamaephytes & Active & Forb & 0.26 & 0.53 & Cat greenbriar & RLMD \\
\hline Smilax laurifolia & Liliaceae & Chamaephytes & Active & Forb & 0.14 & 0.49 & Laurel greenbriar & LMD \\
\hline Smilax rotundifolia & Liliaceae & Chamaephytes & Active & Forb & 0.14 & 0.49 & Roundleaf greenbriar & LM \\
\hline Solanum carolinense & Solanaceae & Hemicryptophyte & Proto & Forb & 0.21 & 0.45 & Carolina horsenettle & RLMD \\
\hline Solidago leavenworthii & Asteraceae & Cryptophyte & Geophyte & Forb & 0.01 & 0.12 & 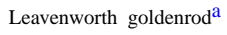 & M \\
\hline Solidago odora & Asteraceae & Cryptophyte & Geophyte & Forb & 0.91 & 1.38 & Anise-scented goldenrod & RLD \\
\hline Solidago stricta & Asteraceae & Cryptophyte & Geophyte & Forb & 0.33 & 0.77 & Slender goldenrod ${ }^{\mathrm{a}}$ & RLD \\
\hline Solidago tenuifolia & Asteraceae & Cryptophyte & Geophyte & Forb & 0.16 & 0.58 & Narrow goldenrod ${ }^{\mathrm{a}}$ & RL \\
\hline Stipulicida setacea & Caryophyllaceae & Hemicryptophyte & Rosette & Forb & 0.03 & 0.17 & Stipulicida $^{\mathrm{a}}$ & M \\
\hline Strophostyles umbellata & Leguminosae & Chamaephytes & Active & Vine & 0.20 & 0.77 & Trailing strophostyles ${ }^{\mathrm{a}}$ & $\mathrm{R}$ \\
\hline Stylosanthes biflora & Leguminosae & Hemicryptophyte & Proto & Forb & 0.16 & 0.50 & Pencil flower & RL \\
\hline Tephrosia virginiana & Leguminosae & Chamaephytes & Suffruticose & Forb & 0.59 & 1.34 & goat's rue & RMD \\
\hline Toxicodendron quercifolia & Anacardiacea & Chamaephytes & Suffruticose & Vine & 0.50 & 1.06 & poison ivy & RL \\
\hline Trichostema dichotomum & Lamiaceae & Therophyte & & Forb & 0.01 & 0.12 & Blue curls & $\mathrm{L}$ \\
\hline Triplasis americana & Graminae & Cryptophyte & Geophyte & Grass & 0.17 & 0.64 & Sand grass & RLM \\
\hline Triplasis purpurea & Graminae & Cryptophyte & Geophyte & Grass & 0.46 & 1.14 & Purple sand grass & LMHD \\
\hline Vaccinium arboreum & Ericaceae & Phanerophyte & Deciduous & Shrub & 0.74 & 1.68 & Farkleberry & RLD \\
\hline Vaccinium eliottii & Ericaceae & Phanerophyte & Deciduous & Shrub & 0.60 & 1.42 & Elliots blueberry & RL \\
\hline Vaccinium myrsinites & Ericaceae & Phanerophyte & Evergreen & Shrub & 0.64 & 1.50 & Shinny blueberry & RLD \\
\hline Vaccinium stamineum & Ericaceae & Phanerophyte & Deciduous & Shrub & 1.06 & 1.80 & Deerberry & RLD \\
\hline Vernonia angustifolia & Asteraceae & Hemicryptophyte & Proto & Forb & 0.26 & 0.61 & Tall ironweed & RL \\
\hline Viola palmata & Violaceae & Hemicryptophyte & Proto & Forb & 0.06 & 0.29 & Palmed violet & $\mathrm{R}$ \\
\hline Vitis rotundifolia & Vitaceae & Chamaephytes & Passive & Vine & 0.04 & 0.20 & Muscadine & $\mathrm{L}$ \\
\hline Wahlenbergia marginata & Campanulaceae & Hemicryptophyte & Proto & Forb & 0.01 & 0.12 & Southern rockbell & $\mathrm{D}$ \\
\hline Yucca filamentosa & Liliaceae & Hemicryptophyte & & Shrub & 0.19 & 0.43 & Adams needle & LMD \\
\hline
\end{tabular}

a No common name was provided by taxonomy books; so, these common names were derived from the Latin name or description.

\section{References}

Adams, A.B., Dale, V.H., Kruckeberg, A.R., Smith, E., 1987. Plant survival, growth-form and regeneration following the May 18, 1980, eruption of Mount St. Helens, Washington. Northwest Sci. 61, 160-170.

Angermeier, P., Karr, J., 1994. Biological integrity versus biological diversity as policy directives: protecting biotic resources. Bioscience 44, 690-697.

Bai, Y.F., Li, L.H., Huang, J.H., Chen, Z.Z., 2001. The influence of plant diversity and functional composition on ecosystem stability of four Stipa communities in the inner Mongolia Plateau. Acta Bot. Sin. 43, 280-287.

Bailey, R., 1995. Description of the Ecoregions of the United States. 2nd Edition, revised and expanded (1st Edition 1980).
Miscellaneous Publication No. 1391 (revised), Washington DC. USDA Forest Service. 108 pp. with separate map at 1:7,500,000. Barbour, M.G., Burk, J.H., Pitts, W.D., 1980. Terrestrial Plant Ecology. The Benjamin/Cummings Publishing Company, Inc., Reading, Massachusetts.

Bråkenhielm, S., Qinghong, L., 1995. Comparison of field methods in vegetation monitoring. Water Air Soil Pollut. 79, 75-87.

Braun-Blanquet, J., 1932. In: George D. Fuller, Henry S. Conard (Eds.), Plant sociology: the Study of Plant Communities, Authorized English translation of Pflanzensoziologie, McGraw-Hill, New York.

Cairns, J., McCormick, P.V., Niederlehner, B.R., 1993. A proposed framework for developing indicators of ecosystem health. Hydrobiologia 236, 1-44.

Clarke, R. (Ed.), 1986. The Handbook of Ecological Monitoring. Claredon Press, Oxford. 
Cochran, W.G., 1954. Some methods for strengthening the common $\chi^{2}$ tests. Biometrics 10, 417-451.

Dale, V.H., Beyeler, S.C., 2001. Challenges in the development and use of ecological indicators. Ecological Indicators, Vol. 1, pp. 3-10.

Dennis, J.V., 1971. Species using red-cockaded woodpecker holes in northeastern South Carolina. Bird-Banding 42, 79-87.

Diersing, V.E., Shaw, R.B., Tazik, D.J., 1992. US army land condition trend analysis (LCTA) program. Environ. Manage. $16,405-414$

Dobrowolski, J.P., Blackburn, W.H., Pearson, H.A., 1992. Changes to infiltration and interrill erosion from long-term prescribed burning in Louisiana. Water Resources Bull. 28, 287-298.

Elliot, D., Holland, J., Thomason, P., Emrick, M., Stoops, R., 1995. Historic Preservation Plan for the Cultural Resources on United States Military Installations at Fort Benning Military Reservation, Chatahoochee and Muskcogee Counties, Georgia, and Russell County, Alabama. National Parks Service Offices, Southeast Regional Offices, Atlanta, GA.

Frost, C., 1993. Four centuries of changing landscape patterns in the longleaf pine ecosystem. Proc. Tall Timbers Fire Ecol. Conf. 18, 17-44.

Gilliam, F.S., Platt, W.J., 1999. Effects of long-term fire exclusion on tree species composition and stand structure in an old growth Pinus palustris (longleaf pine) forest. Plant Ecol. 140, $15-26$.

Godfrey, R., 1988. Trees, Shrubs, and Woody Vines of Northern Florida and Adjacent Georgia and Alabama. University of Georgia Press, GA.

Guntenspergen, G., Levenson, J., 1997. Understory plant species composition in remnant stands along an urban-to-rural land-use gradient. Urban Ecosyst. 1, 155-169.

Haywood, J.D., Tiarks, A.E., Elliott-Smith, M.L., et al., 1998. Response of direct seeded Pinus palustris and herbaceous vegetation to fertilization, burning, and pine straw harvesting. Biomass Bioenerg. 14, 157-167.

Kane, S., Keeton, R., 1998. Fort Benning: the land and the people. Southeast Archeological Center, National Park Service. Tallahassee, FL.

Kershaw, K.A., Looney, J.H., 1985. Quantitative and Dynamic Plant Ecology, 3rd Edition, Arnold, London.

Kirkman, L.K., Goebel, P.C., West, L., Drew, M.B., Palik, B.J., 2000. Depressional wetland vegetation types: A question of plant community development. Wetlands 20, 373-385.

James, F.C., Hess, C.A., Kicklighter, Thum, R.A., 2001. Ecosystem management and the niche gestalt of the red-cockaded woodpecker in longleaf pine forests. Ecol. Appl. 11, 854870.

Mantel, N., 1963. Chi-square tests with one degree of freedom: extensions of the Mantel-Haenszel procedure. J. Am. Stat. Assoc. 58, 690-700.

Mantel, N., Haenszel, W., 1959. Statistical aspects of the analysis of data from retrospective studies of disease. J. Natl. Cancer Inst. 22, 719-748.

McCay, D.H., 2000. Effects of chronic human activities on invasion of longleaf pine forests by sand pine. Ecosystems 3, 283-292.
McIntyre, S., Lavorel, S., Tremont, R.M., 1995. Plant life-history attributes: their relationship to disturbance responses in herbaceous vegetation. J. Ecol. 83, 31-44.

Noss, R., 1989. Longleaf pine and wiregrass: keystone components of an endangered ecosystem. Nat. Areas J. 9, 211-213.

Quicke, H., Meldahl, R., Kush, J., 1994. Basal area growth of individual trees: a model derived from a regional longleaf pine growth study. Forest Sci. 40, 528-542.

Platt, W.J., Evans, G.W., Rathnun, S.L., 1988a. The population dynamics of a long-lived conifer (Pinus palustris). Am. Nat. 131, 491-525.

Platt, W.J., Evans, G.W., Davis, M.M., 1988b. Effects of fire season on flowering of forbs and shrubs in longleaf pine forests. Oecologia 76, 353-363.

Provencher, L., Herring, B.J., Gordon, D.R., Rodgers, H.L., Galley, K.E.M., Tanner, G.W., Hardesty, J.L., Brennan, L.A., 2001. Effects of hardwood reduction techniques on longleaf pine sandhill vegetation in Northwest Florida. Restor. Ecol. 9, 13-27.

Radford, A., Ahles, H., Bell, R., 1968. Manual of the vascular flora of the carolinas. University of North Carolina Press, NC.

Roemer, E., Jackson, T., Lolly, S., Moore, S., Bergstressor, J., 1994. Archaeological Survey at Fort Benning's Compartment C-3 Chattahoochee County, Georgia. PanAmerican Consultants Inc., Tuscaloosa, Alabama, National Park Service Southeast Regional Office, Atlanta, GA.

Stohlgren, T.J., Schell, L.D., Vanden Heuvel, B., 1999. How grazing and soil quality affect native and exotic plant diversity in rocky mountain grasslands. Ecol. Appl. 9, 45-64.

Stewart, A.S., Loar, J. 1994. Spatial and temporal variation in biomonitoring data. In: Loeb, S.L., Spacie, A. (Eds.), Biological Monitoring of Aquatic Systems, Lewis Publishers, Boca Raton, FL.

Thomas, S.C., Halpern, C.B., Falk, D.A., Liguori, D.A., Austin, K.A., 1999. Plant diversity in managed forests: understory responses to thinning and fertilization. Ecol. Appl. 9, 864-879.

USAIC (United State Army Infantry Center), 2001. Integrated Natural Resources Management Plan 2001-2005. Fort Benning Army Installation, Georgia/Alabama, pp. 757.

USDA, Natural Resources Conservation Service (NRCS), 1924. Soil Survey, Chattahochee County, Georgia. US Government, Printing Office, Washington, DC.

USDA, NRCS, 1983. Soil Survey, Muscogee County, Georgia. US Government Printing Office, Washington, DC.

USDA NRCS, 1993. Preliminary Soil Survey, Russel County, Alabama, US Government, Printing Office, Washington, DC.

USDA NRCS, 1997. Soil Survey, Chattahoochee and Marion County, Georgia. US Government, Printing Office, Washington, DC.

Walker, J., 1999. In: Miller, G. L. (Ed.), Proceedings of the Conference on the value of Old Growth Forest Ecosystems of the Eastern United States August 26-28 1993, University of North Carolina, Asheville, NC, pp. 33-40.

Waring, M., Teaford, J., Allen, H., Goeller, T., Schultz, K., Davis, B., Evans, D., Wray, T., 1990. Fort Benning Land-Use Planning and Management Study. Department of the Army Waterways 
Experimental Station, Corps of Engineers. Technical Report EL-90-4.

White, P.S., Pickett, S.T.A. 1985. Natural disturbance and patch dynamics: an introduction. In: S. T. A. Pickett, P. W. White (Eds.), The Ecology of Natural Disturbance and Patch Dynamics. Academic Press, New York, pp. $3-13$
Whitecotton, R.C.A., David, M.B., Darmody, R.G., Price, D.L., 2000. Impact of foot traffic from military training on soil and vegetation properties. Environ. Manage. 26, 697-706.

Yorks, T.P., West, N.E., Mueller, R.J., Warren, S.D., 1997. Toleration of traffic by vegetation: life-form conclusions and summary extracts from a comprehensive data base. Environ. Manage. 21, 121-131. 